\title{
Brexit, Globalisation and the Future of the EU
}

The new EU Global Strategy (EUGS) professes that we live "in a world of predictable unpredictability." Yet, tipping points in international relations have rarely come as clearly scheduled and thoroughly previewed as the "In/Out" referendum in the United Kingdom on 23 June 2016. Like the fall of the Iron Curtain and the subsequent implosion of the Soviet Union, the consequences of Brexit could be momentous. Where the crisis triggered by the collapse of Lehman Brothers in 2008 dealt a major blow to globalisation, defined in terms of international trade and finance, the UK referendum's "Leave" vote has added labour mobility to the equation. While its impact is not expected to spread as quickly as in financial meltdowns, the consequences of the result will not subside anytime soon.

The degree of unpredictability will be partially determined by developments in European politics: will the continent continue to look outwards towards an open global economy or will it be more nationalist and protectionist, reacting against the forces of globalisation? The new Global Strategy was presented to the European Council barely five days after the UK referendum, but it has firmly pointed the EU's foreign policy compass towards a liberal international economic order. While the prescription of acting through the EU as a necessary force multiplier is a commendable strategy for medium-to-small member states, the EUGS nevertheless risks being out of sync with current domestic political developments in several EU countries.

Brexit sets a precedent for disgruntled electorates in other nations to rescind their respective political, legal and economic arrangements and to build walls against the perceived negative forces of globalisation. Presidential hopefuls in France and leaders of right-wing anti-immigration parties in the Netherlands and other member states have welcomed the British move to pull up the drawbridge, calling for "In/Out" referenda in their own countries. These populists most vocally express a feeling that is widely shared around Europe, namely that countries will be better off and have more freedom to act when not constrained by their EU membership. ${ }^{2}$ This myth not only misrepresents the functioning of the EU and the (extended) Single Market; it also fails to understand the nature of sovereignty in a highly connected world defined by global value chains, fast technological advances and growing migration.

The EUGS describes it well:

[W]ith most world growth expected to take place outside the EU in [the] near future, trade and investment will increasingly underpin our prosperity: a prosperous Union hinges on a strong internal market and an open international economic system. We have an interest in fair and open markets, in shaping global economic and environmental rules, and in sustainable access to the global commons through open sea, land, air and space routes. ${ }^{3}$

Increased autonomy calls for greater international cooperation and coordination to absorb the effects of global trends. As former British Prime Minister Gordon Brown observed before the referendum:

1 European Union: Shared Vision, Common Action: A Stronger Europe. A Global Strategy for the European Union's Foreign and Security Policy, June 2016, p. 46.

2 See B. Stokes: Euroskepticism Beyond Brexit, Pew Research Center, 7 June 2016. Early polls conducted in the wake of the UK referendum (e.g. by IFOP between 28 June and 6 July) show a surge of pro-EU sentiment across member states but this effect may wane off quite quickly when headlines turn their attention to challenges posed by immigration, terrorist attacks and banking crisis.

3 European Union, op. cit., pp. 14-15. 
Meeting the needs and aspirations of the British people in the twenty-first century requires us to let go of the past, acknowledge that the present is defined by globalization, and recognize that the future is filled with opportunity. ${ }^{4}$

The UK government's own "Balance of Competences Review" has produced ample evidence that this is best done by working through the European Union.

The genie let out of the Brexit bottle has now alighted in Brussels. Competing interests are starting to emerge as to how the future EU27 and the European institutions should respond, in particular to the issue of globalisation. Whereas EU Trade Commissioner Cecilia Malmström has said that the negotiations with key partners will continue, French Prime Minister Manuel Valls has declared that the TTIP agreement is no longer in the interest of France. Within the German grand coalition, ministers are openly debating their opposing views on TTIP. Since no major change has occurred in the ongoing trade negotiations with the US, this stance can only be interpreted as a politically motivated attempt to appeal to anti-globalist voters.

France, in particular, is key. With French presidential elections scheduled to take place in spring 2017, the questions until then are whether France will be outward- and forward-looking; whether it will want to have a say in how an open and fair international economic system is crafted and how sustainable access to global commons is ensured; and whether it will rally around the EU flag with Germany (which has federal elections in the second half of next year) to save the integration project, or whether it will follow the UK and become a gravedigger of the EU.

The onus now is on all those who wish Brexit to be a positive turning point in the post-Cold War world order to come up with concrete ideas during the period of reflection that the EU27 has called for. Retaining the status quo will mean decline. If ever there was a time for bold proposals to regenerate political momentum for the European integration process, it is now. Thus, the EUGS comes at a particularly auspicious time. Indeed, as asserted in the document, we will need to "equip ourselves to respond more rapidly and flexibly to the unknown lying ahead. A more responsive Union requires change." ${ }^{5}$ Now is a time for engagement, not estrangement.

Meanwhile, the UK's train "breckage" unfolds before us in slow motion, with no clear answers forthcoming on how the UK intends to disentangle itself from the EU machinery. Global market fluctuations are likely to continue for as long as uncertainty reigns. Companies are preparing to move elsewhere and investments are being diverted. Uncertainties about the constitutional contours of the hitherto "United" Kingdom are being compounded by debates about the nature of the country as a future neighbour of the EU. While the comparatively pro-EU Scotland is exploring ways to remain in the European Union, Westminster is contemplating alternatives to the unsatisfactory models pioneered by Norway, Switzerland and other countries. ${ }^{6}$ Arguably, continued membership of the European Economic Area (EEA) would allow the UK and the EU to rebalance their bilateral relationship after the rupture of Brexit. But it is hard to see how ideas entertained by some Brexiteers about an "EEA Minus" status for the UK could be realised, because it would imply that the remaining 27 countries and EU institutions would agree to extend voting rights on the internal market to a non-EU state which intends to restrict the free movement of labour. The UK seemingly wishes to adopt an à la carte form of globalisation with the EU that only includes goods and capital. This is at complete odds with the EU's view of the concept, which holds freedom of movement of labour as an unimpeachable aspect of our globalised world. The chances of the stars aligning favourably for the UK are quite small.

Steven Blockmans, Centre for European Policy Studies, Brussels, Belgium.
4 See G. Brown: Leading, not Leaving, Europe, Project Syndicate, 13 June 2016.

5 European Union, op. cit., p. 46.

6 See J.-C. Piris: If the UK votes to leave: The seven alternatives to EU membership, CER Policy Brief, 12 January 2016. 